\title{
EXPERIMENTAL STUDY ON THE EFFECT OF WATER QUALITY ON STRENGTH OF CONCRETE CASE STUDY: DAL LAKE WATER
}

\author{
Mohammad Shafaq Bazaz \\ Department Of Civil Engineering, RIMT University \\ Opposite Floating Restaurant, Sirhind Side, Mandi- Gobindgarh-147301, Punjab (INDIA)
}

\begin{abstract}
The present work deals with the results of experimental investigations of the effect of water quality on compressive strength of concrete developed with Dal Lake Water as a case study. Two concrete mixes, 1:1.5:3(M20) and 1:1:2(M25), with water / cement ratio of 0.60 were put under investigation. Water samples from four different sites of Dal Lake and Portable water of Treatment Plant Rangil were employed to cast 288 concrete cubes in total. The cured cubes were then crushed under a UTM on day 7, 14, 21, 28, 56 and 84 for determining the compressive strength. The chemical components of the water samples were also determined in the laboratory. The results revealed that the compressive strength of concrete cubes produced with potable water increased significantly with days, while those of Dal Lake didn't show the standard strength. The chemical analyses further revealed that Dal Lake water had concentrations of some chemical parameters on higher side which led to concrete strength reduction. Consequently, adequate water analysis should be encouraged and done before choosing any water for concreting work.
\end{abstract}

Keywords- water analyses, potable water, lake water, compressive strength, concrete mix design, concrete cubes

\section{INTRODUCTION}

The properties of concrete are vital factors that determine to a large extent the strength, durability and serviceability of structures made from it. On one hand, concrete is plastic and malleable in green state, but strong and durable when hardened on the other. These qualities are the driving forces that concrete can be used in the construction of skyscrapers, bridges, etc. There are several factors that determine the quality of concrete as well as its strength. These include the type of cement employed, aggregate quality and grading, the degree of compaction, quality and quantity of water used in concreting, curing method, type of reinforcement embedded including its sizes, arrangement and spacing, etc. Of all the mentioned, most important currently is the quality of the mixing water. Water is a very vital component of concrete as it participates in chemical reaction with cement with great endeavour. Since it helps in the formation of strength giving cement gel, its quantity and quality is needed to be looked into very carefully and in depth. In practice very often huge control on properties of cement and aggregates is exercised, but the control on quality of water is often ignored. Since quality of water affects the strength, it is necessary for us to go into purity and quality of water. A popular yard stick to the suitability of water for mixing concrete is that, if water is fit for consumption, it is fit for use in concrete as well. Water possessing acids, alkalies, decayed vegetable matter and other unwanted constituents reduce the strength of concrete significantly, and hence should not be used. Sea water also decreases the strength of concrete by about $10 \%$ $20 \%$ as compared to fresh water used. Maximum allowed concentration of different harmful elements as recommended by I.S.I is as follows:

1) In order to neutralise $200 \mathrm{ml}$ of water, it should not need more than $2 \mathrm{ml}$ of 0.1 normal $\mathrm{NaOH}$.

2) In order to neutralise $200 \mathrm{ml}$ of water, it should not need more than $10 \mathrm{ml}$ of 0.1 normal HCL.

3) Percentage of solids present in water must not exceed the following permissible limits:

$\begin{array}{ll}\text { Organic solids } & 0.025 \% \\ \text { Inorganic solids } & 0.35 \% \\ \text { Sulphates } & 0.06 \% \\ \text { Alkali chlorides } & 0.12 \%\end{array}$

In case of any doubt or queries, the engineer or supervisor in charge should conduct compressive strength test on concrete. Compressive strength shown by concrete should not in any condition be lower than $90 \%$ of the strength as shown by concrete produced with distilled/portable water.

\section{LITERATURE REVIEW}

The quality of water and its constituent chemicals plays a very vital and important role, impurities and deleterious materials in water can significantly interfere with the setting of the cement paste, drastically effect the strength and other properties of the concrete as well as cause straining on the surface and corrosion of the reinforcement embedded as well. (Niville, 1996) (Stienour,1960) also concurred that some particular types of water can significantly effect the performance hardened concrete, sometimes effect being harmless or beneficial or vice versa when in mixing. In 


\section{International Journal of Engineering Applied Sciences and Technology, 2020 \\ Vol. 5, Issue 5, ISSN No. 2455-2143, Pages 241-248 \\ Published Online September 2020 in IJEAST (http://www.ijeast.com)}

planning the specifications for various civil engineering projects, the water needed is covered in a separate clause mentioning clearly it must be fitted for drinking purposes.

Water suitable for drinking is mostly satisfactory, but there are exceptional cases as well sometimes. For example, in particular arid areas, local drinking water is saline in nature and sometimes possesses an undesirable quantity of chloride, excessive quantity of alkali carbonates and bicarbonates that can drastically contribute to the alkali-silica reaction (Niville, 1996). On the other hand some water which is not fit for drinking can however be suitable for use in concrete production (Portland cement Association, 2005). (McCoy, 1978) suggested that water with $\mathrm{pH}$ range between 6.0 to 8.0 is good for concreting purpose. (Mc-Coy, 1956) opined the use of water having $\mathrm{pH} 9.0$ or above, that does not taste brackish in concrete production.

Compressive strength of concrete, mineral composition, chloride admittance, and rusting of steel bars reinforced in concrete produced with seawater and portable water were put under investigation based on a number of long- term exposures under tidal environment. Seawater- employed concrete showed strength gain. After 30 years of exposure, no drastic difference in the compressive strength of concrete was seen in concrete mixed with seawater and tap water (Mohammad ett aal, 2004). (Kuashik and Islam, 1995) investigated the mixing as well as curing effect of sea water on setting time of concrete, compressive strength of cement-sand mortar and corresponding concrete, reinforced steel bars corrosion, chloride quantity, and variation of alkalinity over a span of 1.5 years in a lab simulated splash/tidal zone of marine environment. The test results showed that sea water was not fit for the mixing and curing of both plain and reinforced concrete in marine conditions.

\section{METHODOLOGY}

\section{Preparation of Samples}

Well graded machine crushed boulder angular in shape of size $10 \mathrm{~mm}$ to $20 \mathrm{~mm}$ bought from a crushing plant situated in Watalbagh Ganderbal was used as coarse aggregate. The fine aggregate, clean river sand whose maximum size was $4.75 \mathrm{~mm}$, conforming to grading zone II was obtained from river Sindh also situated in Ganderbal. About five bags of Saifco Next ordinary Portland cement of grade 43 conforming to IS -8112 were purchased and used throughout the research work. Formwork (moulds) made of tin, size $150 \mathrm{~mm} \times 150 \mathrm{~mm} \times 150 \mathrm{~mm}$ were purchased from the market with the inside surface coated with oil/lubricant.

In order to check the water quality of the Dal Lake, four sites were selected namely Hazratbal basin, Nishat basin, Dalgate channel and Nowpora channel. Water quality standards of water samples taken from the above sites were checked. Various tests to determine various parameters were conducted. The water samples were collected with the help of sampler.

\section{Preparation of Concrete}

The workable concrete mix design, M20 and M25 grade has been prepared using the guidelines as per IS: 10262-
2009. The batching of materials used in concrete was done by weighing each material. The mixing of concrete components (water, cement and aggregate) was done manually, on a clean hard surface to produce homogeneous fresh concrete. Water / cement ratio of 0.60 was maintained throughout the concrete cubes production. The cubes, 288 in number, still in moulds were left overnight at room temperature for drying purpose without being disturbed. At the end of this period, the moulds were stripped and the cubes were then cured in a bucket filled with potable water by completely immersing them inside throughout the cubes compressive strength determinationperiod.

\section{Compressive Strength Test}

Compressive Strength is the most vital as well as important property of hardened concrete. Compressive Strength Test is done to determine the Compressive Strength of concrete. For cube compression testing of concrete, $150 \mathrm{~mm} \times 150 \mathrm{~mm} \times 150 \mathrm{~mm}$ cubes were put to use. Each of the cubes was tested in saturated condition, after wiping out the moisture from the surface. The tests were then carried out after the specimen had been properly centered, with the cast faces in contact with the platens of the testing machine. Load was continually put till the specimen failed and reading noted down from the automatic universal testing machine. The test was performed at end of 7th, 14th, $21 \mathrm{st}, 28 \mathrm{th}, 56 \mathrm{th}$ and 84 th day of concreting. The ultimate load divided by the cross sectional area of the specimen is equal to the ultimate cube compressive strength.

$\mathrm{fc}=\mathrm{P} / \mathrm{A}$

Where,

$\mathrm{fc}=$ compressive strength $(\mathrm{MPa})$

$\mathrm{P}=$ load (Newton)

$\mathrm{A}=$ area of the specimen $(\mathrm{mm})$

\section{Water Samples Analyses}

The representative water samples collected were then taken to laboratory in order to analyse them. The parameters that help in asserting quality, as well as properties of raw water are referred to as "water quality parameters".

- Physical: The parameters which assist in asserting physical qualities of water are known as physical water quality parameters. Physical water quality parameters are those that can be felt or sensed by our respective senses.
Taste
Turbidity Colour
Odour
Temperature

- Chemical: The parameters which help in determining the chemical characteristics or quality of water are termed as chemical water quality parameters. These include:
Total Solids Alkalinity PH
Hardness
Nitrogen content
Chloride content
Fluoride content
Phosphates 


\section{Conductivity}

Dissolved oxygen

Alkalinity

Metals and other chemical substances

- Biological: The biological analysis of water is done to determine the presence of bacteria as well as other minute organisms in water. These microorganisms are minute single cellular which are universally found in water obtained from any source. They very small measuring only 1 to 4 micron in length. For detecting the presence of bacteria of coliform group and measuring their concentration in water the following methods are used:

Total Count or Agar Plate Count Test
E- Coli Test

Membrane Filter Technique

\section{RESULTS AND DISCUSSIONS}

The chemical components of the five water samples taken were determined and the results of the chemical properties are shown in Table A. At the end of 7th, 14th, 21st, 28th 56th and 84th days, four cubes from every mix type as well as water sample were taken for ascertaining compressive strength. 48 cubes were crushed at each test day. At the end of 84 days, 288 cubes were crushed altogether. The results of the compressive strength of concrete cubes are shown In Table B.

Table A: Results of water test

\begin{tabular}{|l|l|l|l|l|l|}
\hline S.no. & Parameters & Nishat & Hazratbal & Dalgate & Nowpora \\
\hline 1. & Temperature[ ${ }^{\circ}$ c] & 6.5 & 6.5 & 6.5 & 6.5 \\
\hline 2. & Colour & Colourless & Colourless & Colourless & Earthy \\
\hline 3. & Odour [cold] & Very faint & Odourless & Faint & Faint \\
\hline & Odour [hot] & Grassy & Grassy & Grassy & Fishy \\
\hline 4. & Conductivity [us] & 277 & 312 & 358 & 690 \\
\hline 5. & Ph & 6.4 & 6.6 & 6.3 & 9.9 \\
\hline 6. & TDS[PPM] & 132 & 153 & 158 & 346 \\
\hline 7. & Suspended solids [PPM] & 60 & 140 & 60 & 157 \\
\hline 8. & Dissolved oxygen [PPM] & 6.8 & 5.6 & 6.8 & 4 \\
\hline 9. & Chloride content[PPM] & 71 & 50 & 92 & 98 \\
\hline 10. & Fluoride content [PPM] & 0.5 & 0.3 & 0.9 & 1.5 \\
\hline 11. & Iron content [PPM] & 0.21 & 0.31 & 0.35 & 0.35 \\
\hline 12. & Nitrates [PPM] & 0.521 & 0.484 & 0.653 & 0.422 \\
\hline 13. & Nitrites [PPM] & 0.10 & 0.20 & 0.20 & 0.30 \\
\hline 14. & Ammonia [PPM] & 0.35 & 0.10 & 0.45 & 3.5 \\
\hline 15. & Turbidity [NTU] & 3.6 & 1.6 & 4.5 & 34.5 \\
\hline 16. & E-COLI & Negative & Negative & Negative & Positive \\
\hline 17. & Ortho Phosphate [ppm] & 0.244 & 0.360 & 0.290 & 0.855 \\
\hline 18. & Total Hardness [ppm] & 110 & 133.3 & 113.33 & 590.66 \\
\hline 19. & Permanent Hardness [ppm] & 103.3 & 93.3 & 96.66 & \\
\hline & & & & & \\
\hline
\end{tabular}


International Journal of Engineering Applied Sciences and Technology, 2020

Vol. 5, Issue 5, ISSN No. 2455-2143, Pages 241-248

Published Online September 2020 in IJEAST (http://www.ijeast.com)

\begin{tabular}{|l|l|l|l|l|l|}
\hline 20. & Temporary Hardness [ppm] & 6.67 & 40 & 16.67 & 193.34 \\
\hline 21. & BOD [ppm] & 8.01 & 7.22 & 6.27 & 6.55 \\
\hline 22. & Alkalinity [ppm] & 1250 & 3250 & 3000 & 1250 \\
\hline 23. & $\mathrm{OH}^{-}[\mathrm{ppm}]$ & 500 & 1300 & 1200 & 500 \\
\hline
\end{tabular}

Table B: The compressive strength of cubes

\begin{tabular}{|c|c|c|c|c|c|}
\hline $\begin{array}{l}\text { Period of } \\
\text { Cube } \\
\text { Crushing }\end{array}$ & $\begin{array}{c}\text { Water Sample } \\
\text { Type }\end{array}$ & Concrete Mix & $\begin{array}{l}\text { Compressive } \\
\text { Strength, } \\
\text { (N/mm2) } \\
\text { (minimum) }\end{array}$ & $\begin{array}{l}\text { Compressive } \\
\text { Strength, } \\
\text { (N/mm2) } \\
\text { (maximum) }\end{array}$ & $\begin{array}{l}\text { Compressive } \\
\text { Strength, } \\
(\mathrm{N} / \mathrm{mm} 2) \\
(\mathrm{mean})\end{array}$ \\
\hline \multirow[t]{10}{*}{$7^{\text {th }}$ Day } & Nishat & $1: 1: 2$ & 22 & 23.8 & 22.8 \\
\hline & Hazratbal & & 23 & 24.2 & 23.9 \\
\hline & Dalgate & & 22.4 & 24.1 & 23.2 \\
\hline & Nowpora & & 22.4 & 24 & 23 \\
\hline & Tap Water & & 24.2 & 27.7 & 26.1 \\
\hline & Nishat & $1: 1.5: 3$ & 18.1 & 19.1 & 18.6 \\
\hline & Hazratbal & & 19.1 & 20.5 & 19.9 \\
\hline & Dalgate & & 19.3 & 20.7 & 20.2 \\
\hline & Nowpora & & 18 & 19 & 18.5 \\
\hline & Tap Water & & 19.8 & 22.6 & 21.4 \\
\hline \multirow[t]{10}{*}{$14^{\text {th }}$ Day } & Nishat & $1: 1: 2$ & 26.4 & 28.2 & 27.1 \\
\hline & Hazratbal & & 27.4 & 29.3 & 28.2 \\
\hline & Dalgate & & 26.6 & 27.8 & 27.1 \\
\hline & Nowpora & & 25.2 & 26.6 & 26 \\
\hline & Tap Water & & 27.4 & 30.5 & 29 \\
\hline & Nishat & $1: 1.5: 3$ & 22 & 23.5 & 23.1 \\
\hline & Hazratbal & & 23.7 & 25.6 & 25 \\
\hline & Dalgate & & 23.7 & 25.6 & 24.7 \\
\hline & Nowpora & & 23 & 24.9 & 24.1 \\
\hline & Tap Water & & 25.4 & 27.7 & 26.6 \\
\hline \multirow[t]{4}{*}{$21^{\text {st }}$ Day } & Nishat & $1: 1: 2$ & 32 & 33.1 & 32.7 \\
\hline & Hazratbal & & 31.1 & 32.6 & 32 \\
\hline & Dalgate & & 30.7 & 31.2 & 30.9 \\
\hline & Nowpora & & 28.2 & 29 & 28.5 \\
\hline
\end{tabular}


International Journal of Engineering Applied Sciences and Technology, 2020

Vol. 5, Issue 5, ISSN No. 2455-2143, Pages 241-248

Published Online September 2020 in IJEAST (http://www.ijeast.com)

\begin{tabular}{|c|c|c|c|c|c|}
\hline & Tap Water & & 34.1 & 36.3 & 35.1 \\
\hline & Nishat & $1: 1.5: 3$ & 26 & 27.5 & 26.5 \\
\hline & Hazratbal & & 25.5 & 28 & 26.3 \\
\hline & Dalgate & & 25.8 & 26.7 & 26.4 \\
\hline & Nowpora & & 24.8 & 25.3 & 25 \\
\hline & Tap Water & & 28.7 & 31.8 & 30.5 \\
\hline \multirow[t]{10}{*}{$28^{\text {th }}$ Day } & Nishat & $1: 1: 2$ & 38.9 & 41 & 40.1 \\
\hline & Hazratbal & & 40.5 & 41.7 & 40.9 \\
\hline & Dalgate & & 40.6 & 41.1 & 40.8 \\
\hline & Nowpora & & 38 & 39.2 & 38.5 \\
\hline & Tap Water & & 43.5 & 45 & 43.9 \\
\hline & Nishat & $1: 1.5: 3$ & 31 & 31.9 & 31.4 \\
\hline & Hazratbal & & 33.1 & 34 & 33.3 \\
\hline & Dalgate & & 30.1 & 32 & 31.4 \\
\hline & Nowpora & & 32 & 33.5 & 33 \\
\hline & Tap Water & & 36 & 38 & 36.9 \\
\hline \multirow[t]{10}{*}{$56^{\text {th }}$ Day } & Nishat & $1: 1: 2$ & 42.1 & 43.5 & 42.5 \\
\hline & Hazratbal & & 44 & 46.6 & 45 \\
\hline & Dalgate & & 38.9 & 40.3 & 39.7 \\
\hline & Nowpora & & 40.1 & 42.9 & 41.2 \\
\hline & Tap Water & & 47.6 & 49.3 & 48.5 \\
\hline & Nishat & $1: 1.5: 3$ & 36.6 & 38.5 & 37.8 \\
\hline & Hazratbal & & 36.7 & 40.8 & 39.1 \\
\hline & Dalgate & & 36.1 & 39.4 & 38.8 \\
\hline & Nowpora & & 35.5 & 38 & 36.8 \\
\hline & Tap Water & & 38.9 & 41.7 & 40.1 \\
\hline \multirow[t]{7}{*}{$84^{\text {th }}$ Day } & Nishat & $1: 1: 2$ & 44 & 46.5 & 45.5 \\
\hline & Hazratbal & & 47.9 & 49.4 & 48.8 \\
\hline & Dalgate & & 46.8 & 48.2 & 47.8 \\
\hline & Nowpora & & 46.5 & 48 & 46.8 \\
\hline & Tap Water & & 49.6 & 52.1 & 51.6 \\
\hline & Nishat & $1: 1.5: 3$ & 38.5 & 39.9 & 39 \\
\hline & Hazratbal & & 36.9 & 38 & 37.6 \\
\hline
\end{tabular}


International Journal of Engineering Applied Sciences and Technology, 2020

Vol. 5, Issue 5, ISSN No. 2455-2143, Pages 241-248

Published Online September 2020 in IJEAST (http://www.ijeast.com)

\begin{tabular}{|l|l|l|l|l|l|}
\hline & Dalgate & & 36.2 & 37.5 & 36.7 \\
\hline & Nowpora & & 39.1 & 41 & 40.6 \\
\hline & Tap Water & & $\mathbf{4 2 . 6}$ & $\mathbf{4 4 . 8}$ & $\mathbf{4 3 . 2}$ \\
\hline
\end{tabular}

The results obtained after the chemical analyses revealed that the four water samples collected have varied concentrations of chemical compositions. Further, the chemical properties of potable water from the Rangil Treatment Plant were much lesser than that of water of Dal Lake. The compressive strength of cubes made with potable water increased with age as displayed in Figures A and B. In initial 28 days, the increase in strength was very quick but in later period, the rate of strength development decreased as conjecture for a normal concrete. However, on the other side, the strength development of cubes produced with Dal Lake water was not as that quick when compared with those of potable water as shown in Figures A and B. The cubes started to lose compressive strength after 14th day of concreting as compared to cubes made from portable water.

Referring to Table B for concrete mix ratio of 1:1:2, after 28 days the mean compressive strength of cubes made with potable water had a mean compressive strength of $43.9 \mathrm{~N} / \mathrm{mm} 2$ whereas the cubes cast with Dal Lake water had a mean compressive strength less than $41 \mathrm{~N} / \mathrm{mm} 2$. On the other hand, the 28th day mean compressive strengths of concrete cubes of mix ratio 1:1.5:3 cast with water from Nishat, Hazratbal, Dalgate and Nowpora were 31.4, 33.3, 31.4 and $33 \mathrm{~N} / \mathrm{mm} 2$ respectively. For the concrete cube of tap water of mix ratio $1: 1.5: 3$, the 28 th day compressive strength was as high as $36.9 \mathrm{~N} / \mathrm{mm} 2$. This indicates clearly that the water from Dal Lake contains chemicals that retard development of concrete compressive strength. On comparing with chemical constituents of portable water, these can be attributed to the presence of very high concentrations of Sodium, Potassium, chloride, fluoride, iron, ammonia, turbidity and BOD as well. In addition, Dal Lake water was more acidic than portable water. Moreover, the Dal Lake water had relatively high $\mathrm{pH}$ value prohibiting its usefulness in concrete production.

Figure A: Compressive strength of concrete cubes with workable mix M20

\section{Chart Title}

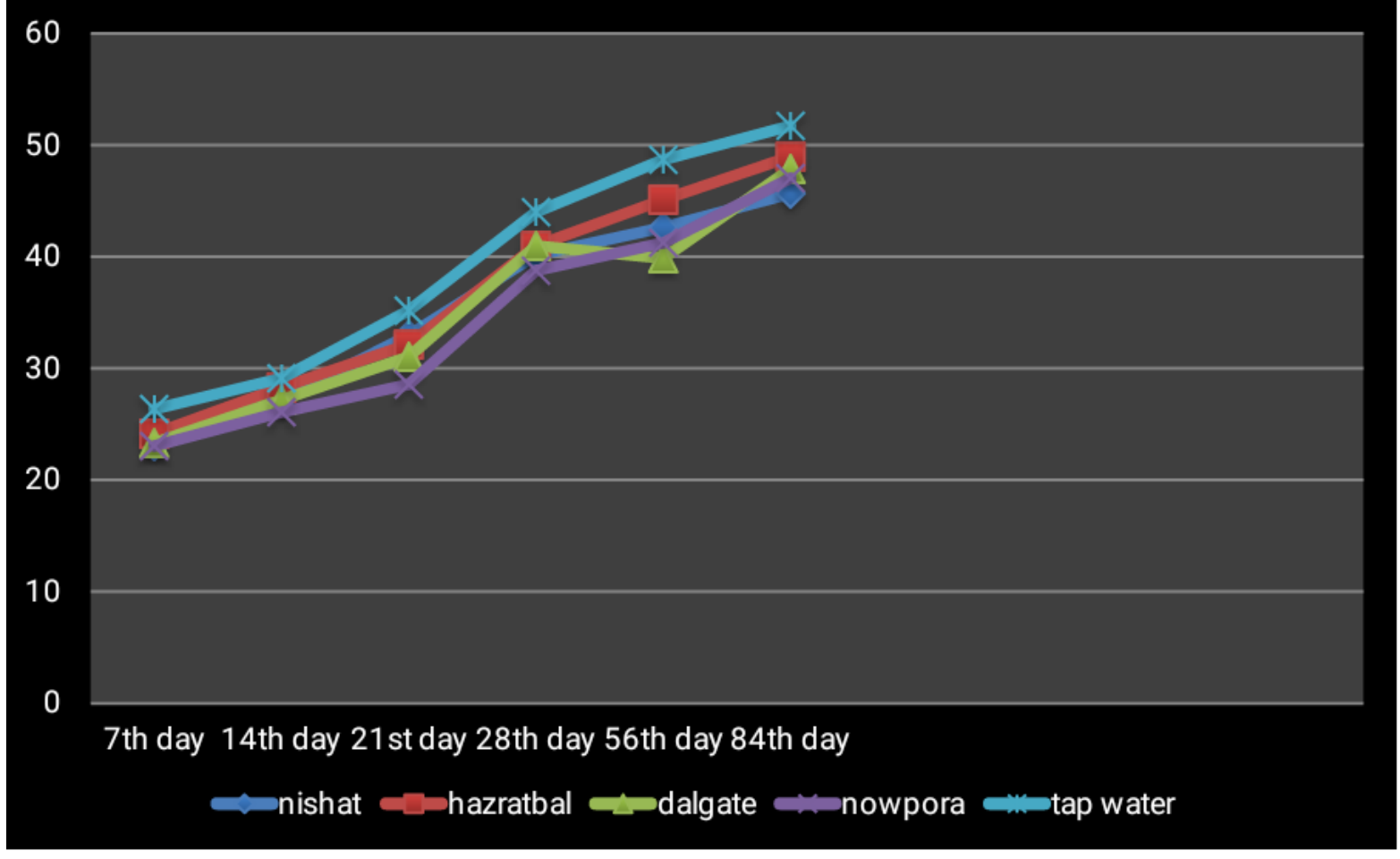


Figure B: Compressive strength of concrete cubes with workable mix M25

\section{Chart Title}

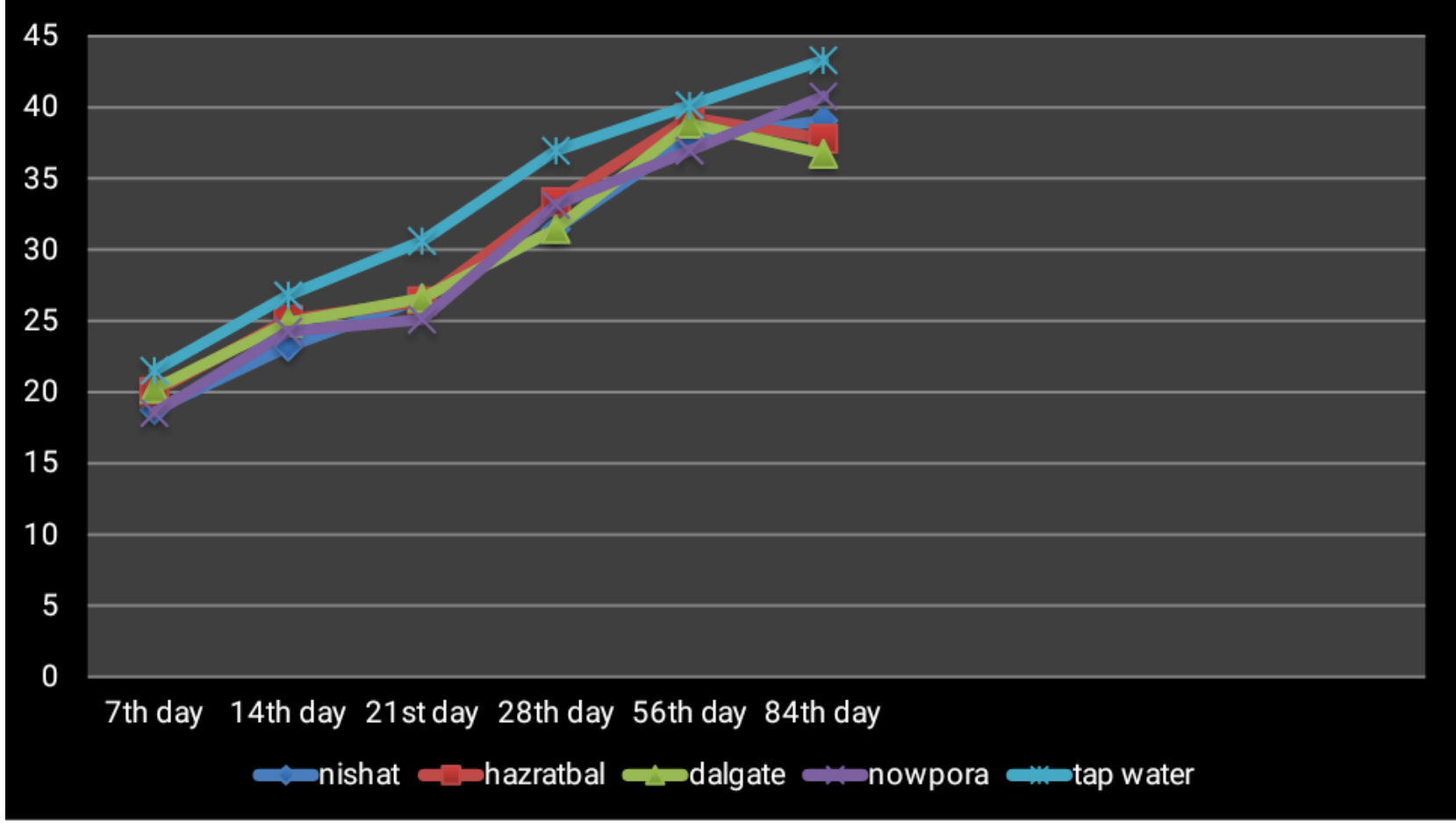

\section{CONCLUSIONS}

The extensive and rigorous study of the effect of water obtained from four sections of Dal Lake on concrete compressive strength has been carried out. The following facts haveemerged:-

It is observed the water quality of Dal Lake has been deteriorated to a great extent. As per study, surveys and investigations, pertaining to the various basins, the rising disturbances from the different anthropogenic sources are real causes of deterioration of the water quality to such a great extent. The condition of basins seems to be deteriorating because of increasing pressure of tourism, sewage disposal and the people living in and around the lake.

Dal Lake water contains relatively higher concentrations of chemicals, that prohibit the development of concrete compressive strength upto a certain extent.

In general, for all construction works that involves use of concrete and its products, the need to investigate suitability of water proposed to be used for concreting prior to commencement of work should be strengthened by all structural and civil engineers.

Potable water is relatively scarce in almost all developing and third world countries, so the pressure is always there to use available water on site. The engineer or supervisor in charge of construction work should make it sure that contractors and companies comply strictly with specifications of water for concrete work.

\section{REFERENCES}

[1]43 Grade Ordinary Portland cement, Specification IS 8112:1989, Bureau of Indian Standards, New Delhi, India.

[2]Celik T, Marar K (1996, Effects of crushed stone dust on some properties of concrete, Cement Concrete

Res-26(7):1121-1130.

[3] Galetakis M, Raka S (2004), Utilization of limestone dust for artificial stone production: an experimental approach. Miner. Eng., 17:355-357.

[4] De Larrard F, Belloc A (1997)., The influence of aggregate on the compressive strength of normal and high-strength concrete. ACI Mater J., 94(5):417-426.

5]Specification for Coarse and Fine Aggregates from Natural Sources for Concrete., IS: 383-1970, Bureau of Indian Standards, New Delhi.

[6] Recommended Guidelines for Concrete Mix Design. ,IS: 10262-1982, Bureau of Indian Standards, New Delhi.

[7]Methods of Sampling and Analysis of Concrete. ,IS: 11991959, Bureau of Indian Standards, New Delhi. 
[8] Methods of Tests for Strength of Concrete,. IS: 516-1959, Bureau of Indian Standards, New Delhi.

[9] Methods of Tests for Strength of Concrete., IS: 516-1959, Bureau of Indian Standards, New Delhi.

[10] Building Construction and Material by Gurcharan Singh

[11] Water Supply Engineering by Dr. P N Modi

[12] Concrete Technology by M S Shetty 